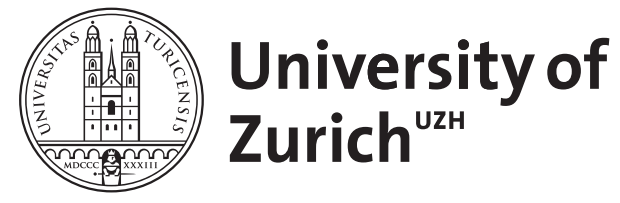

\title{
Methodik in der Rechtsanwendung
}

\author{
Biaggini, Giovanni
}

Posted at the Zurich Open Repository and Archive, University of Zurich ZORA URL: https://doi.org/10.5167/uzh-213217

Book Section

Originally published at:

Biaggini, Giovanni (2004). Methodik in der Rechtsanwendung. In: Peters, Anne; Schefer, Markus. Grundprobleme der Auslegung aus Sicht des öffentlichen Rechts: Symposium zum 60. Geburtstag von René Rhinow. Bern: Stämpfli, 27-51. 


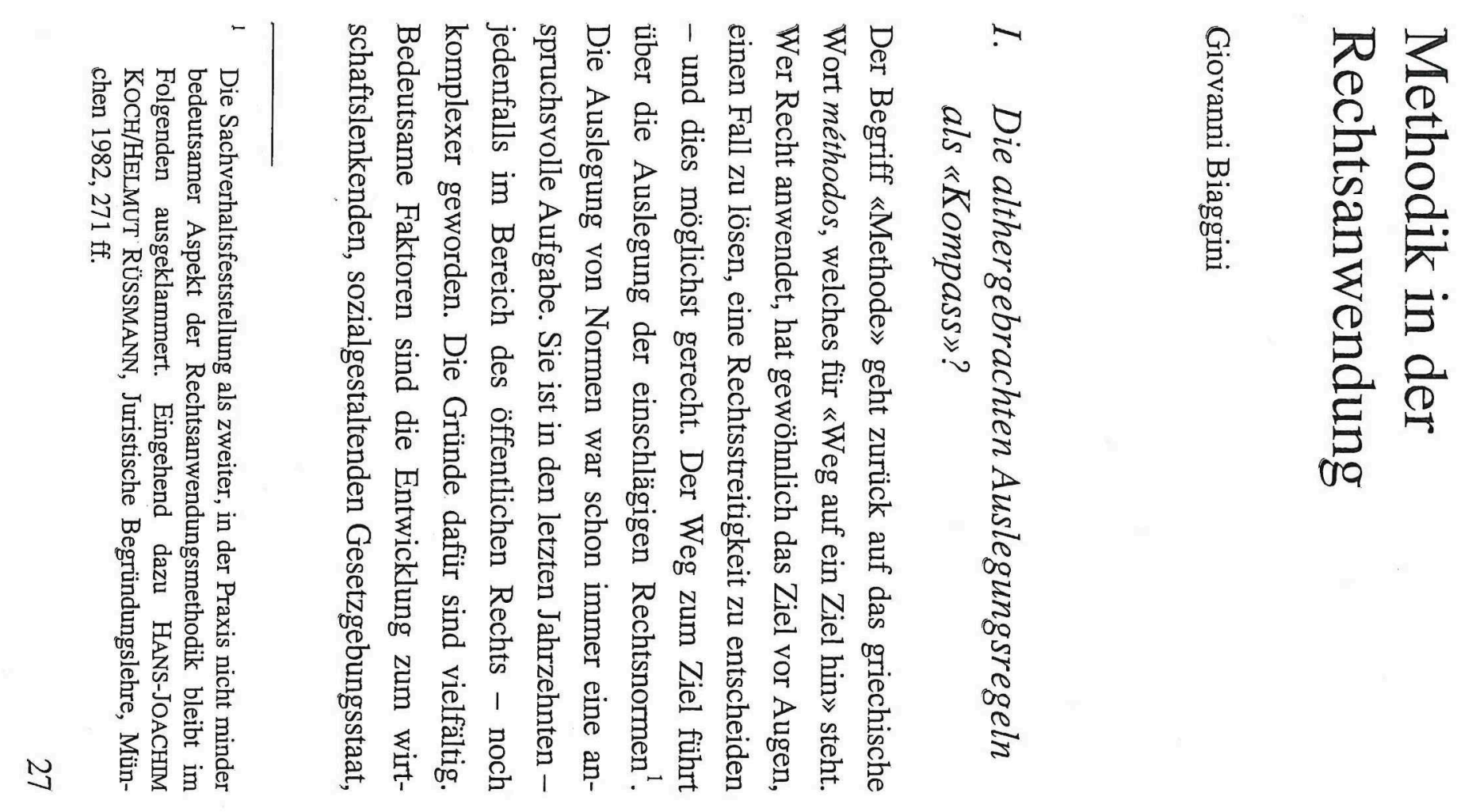


悉

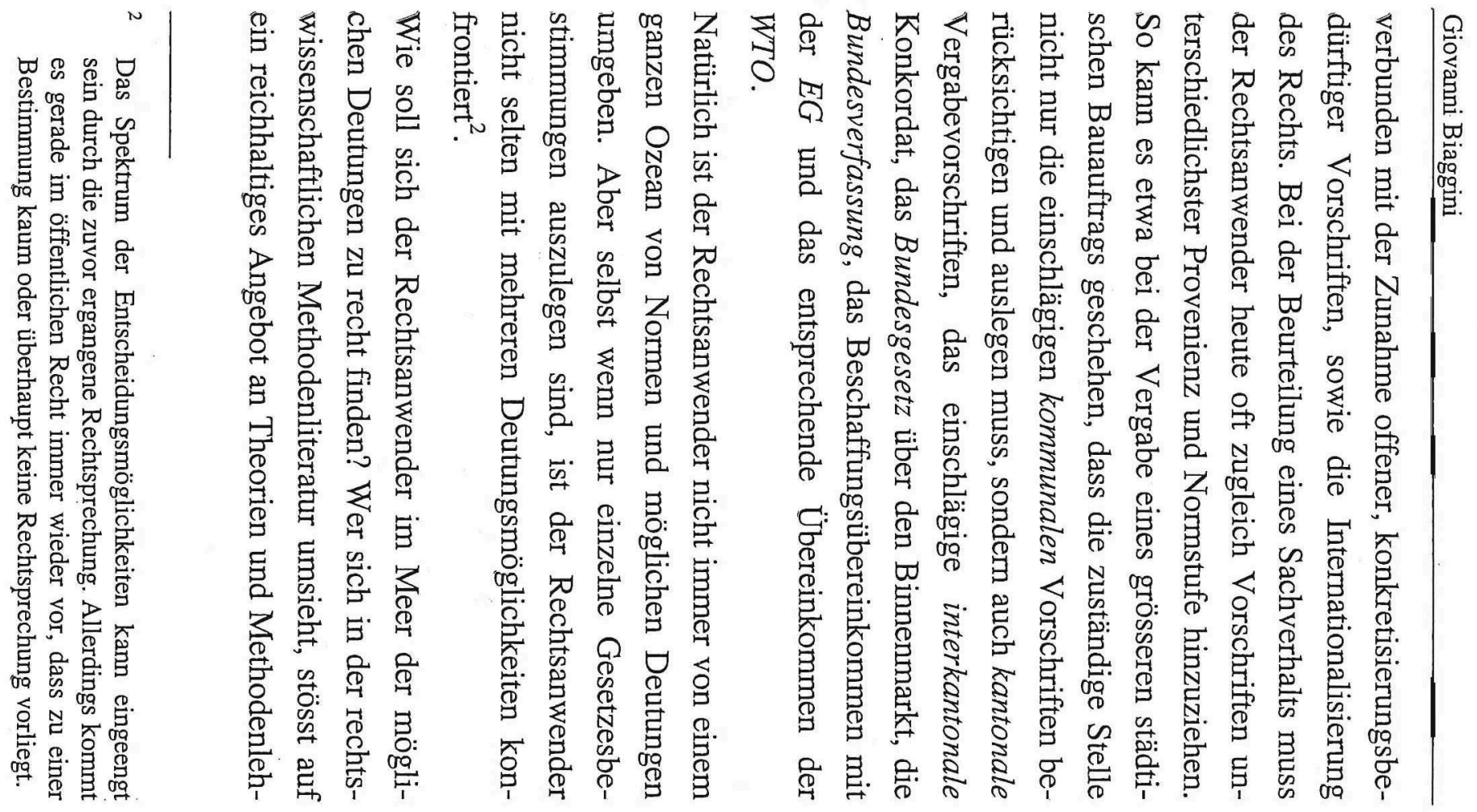

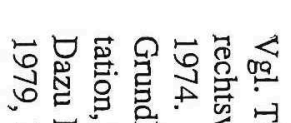

元的高

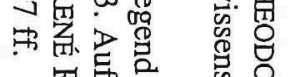

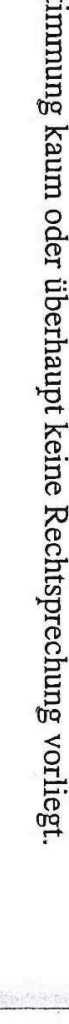
旁翼旁

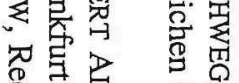

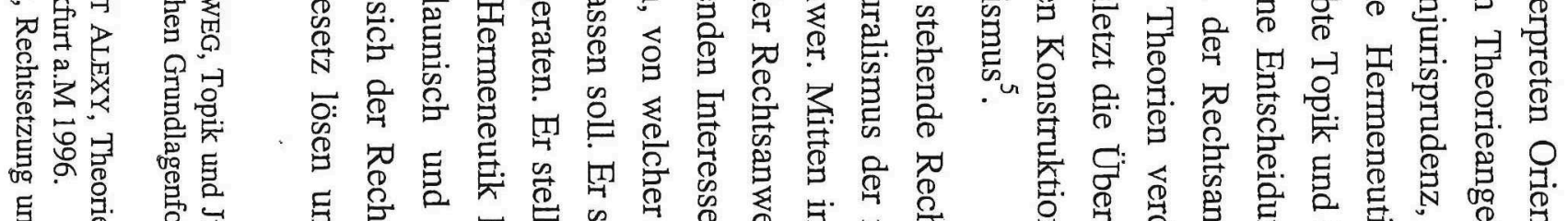

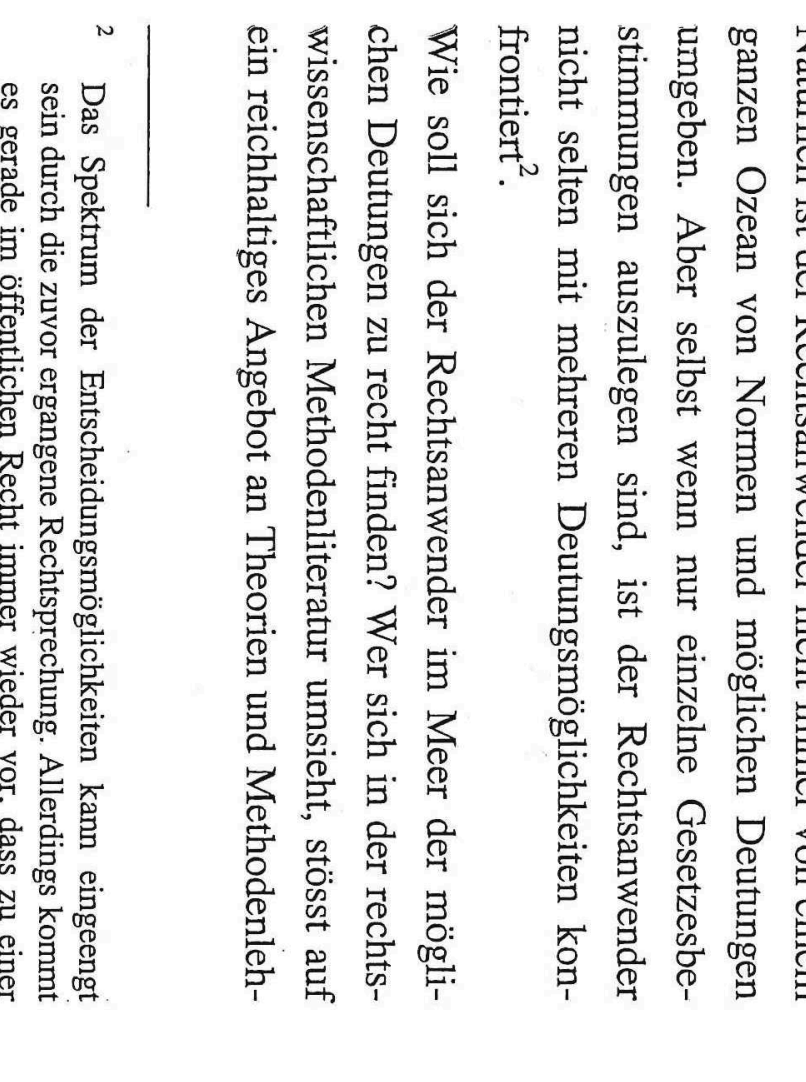

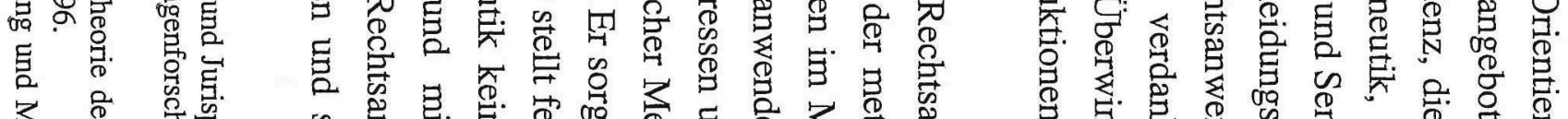

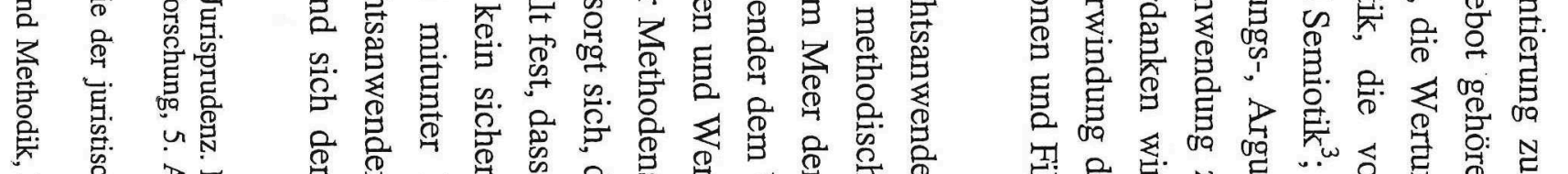

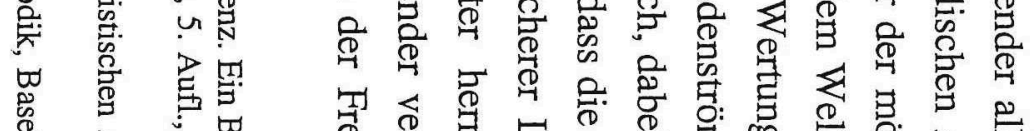

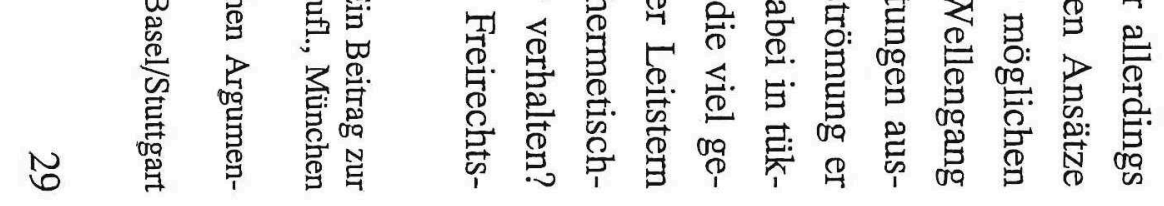


$\omega$

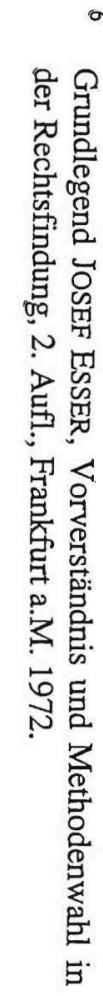

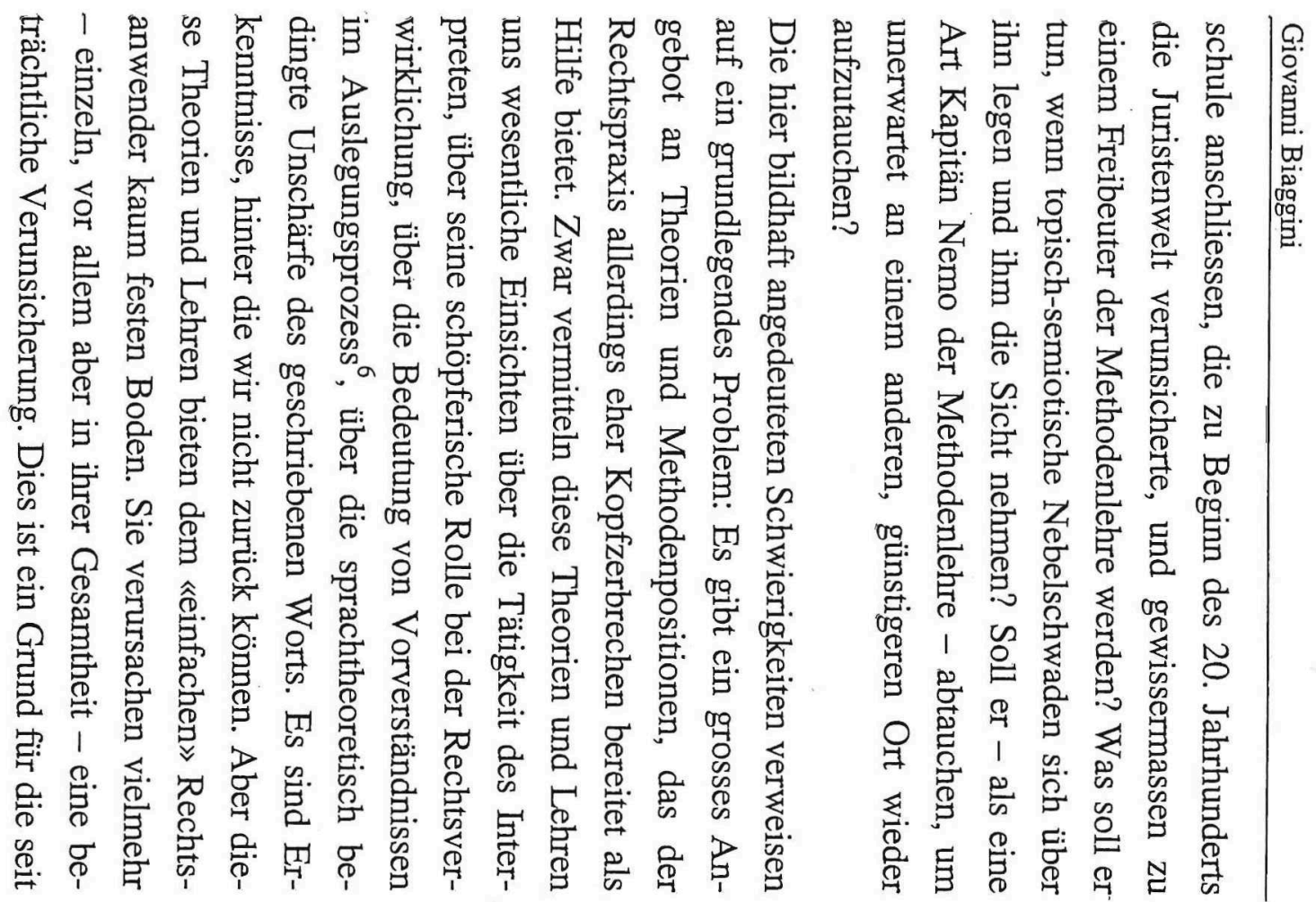

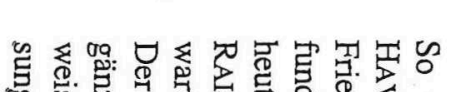

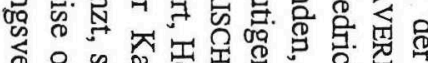

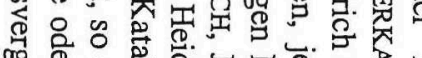

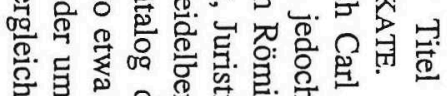

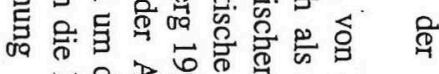

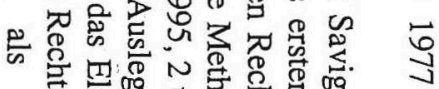

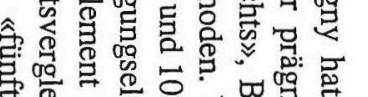

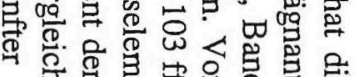

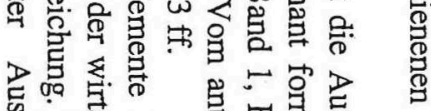

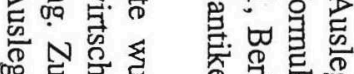

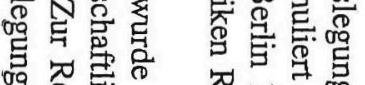
号逼费

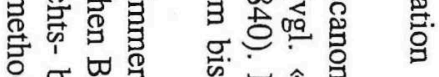

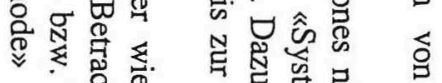

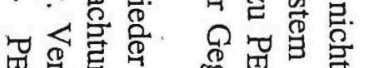

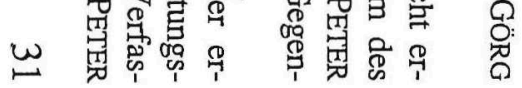

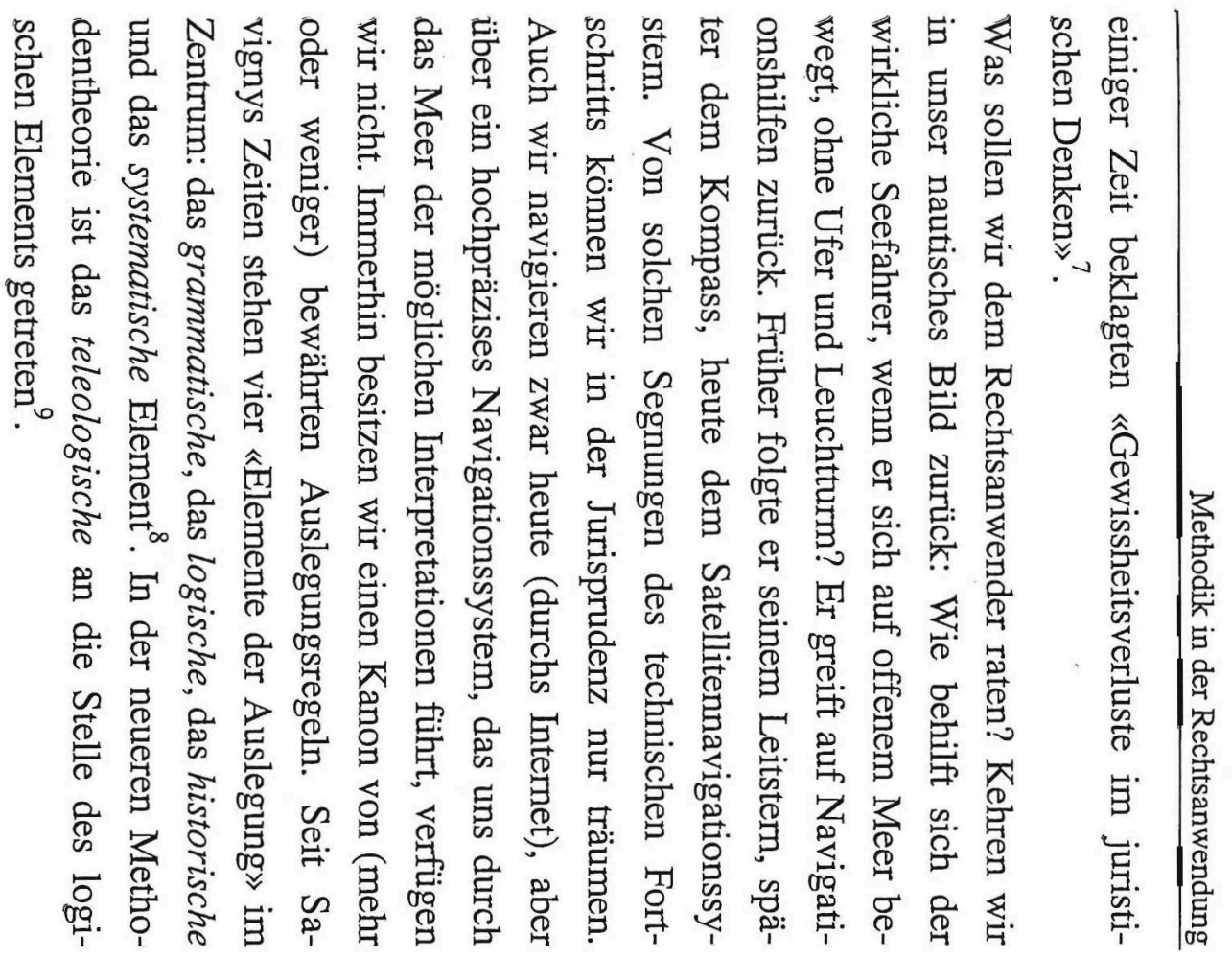


$\omega$

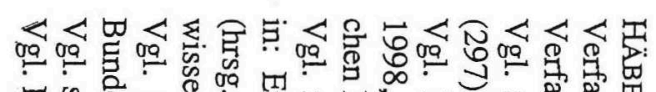

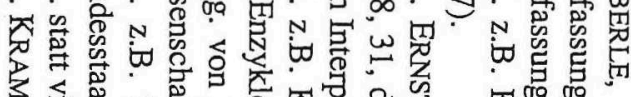

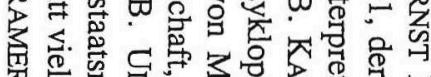

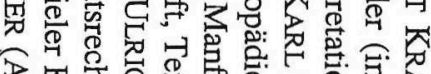

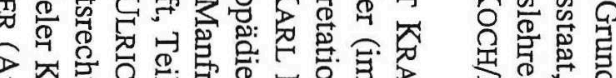

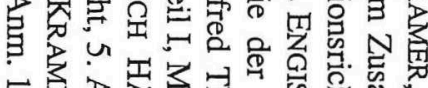

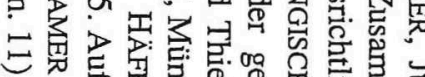

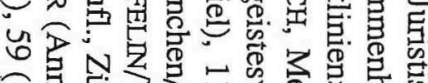

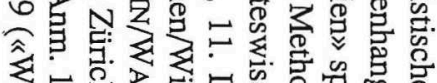

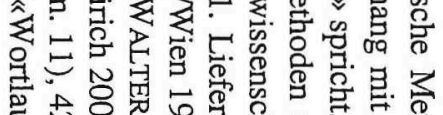

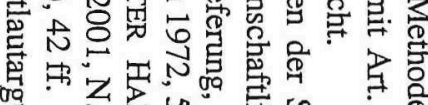

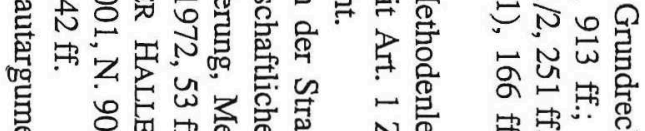

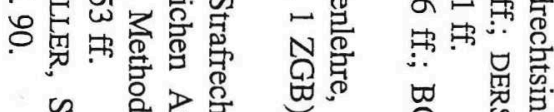

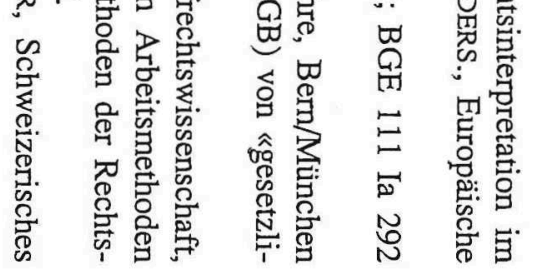

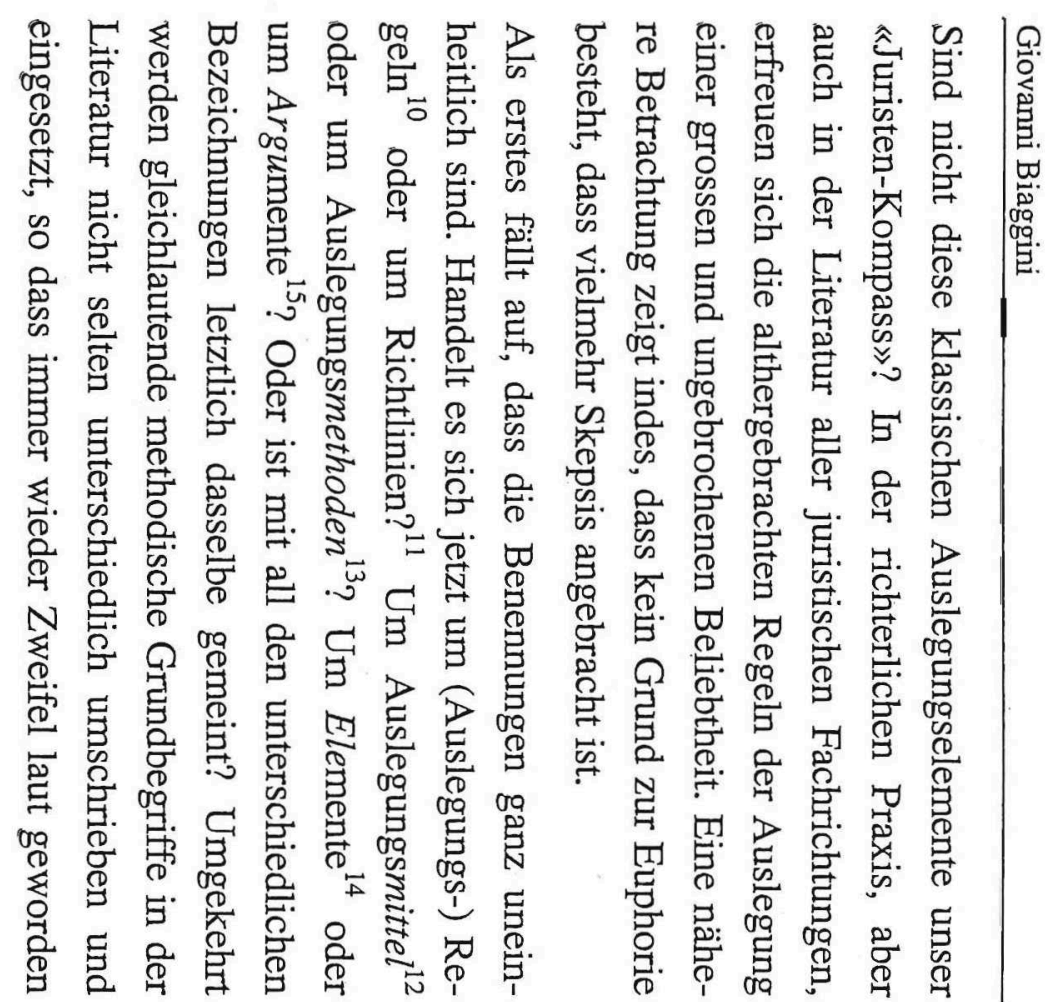

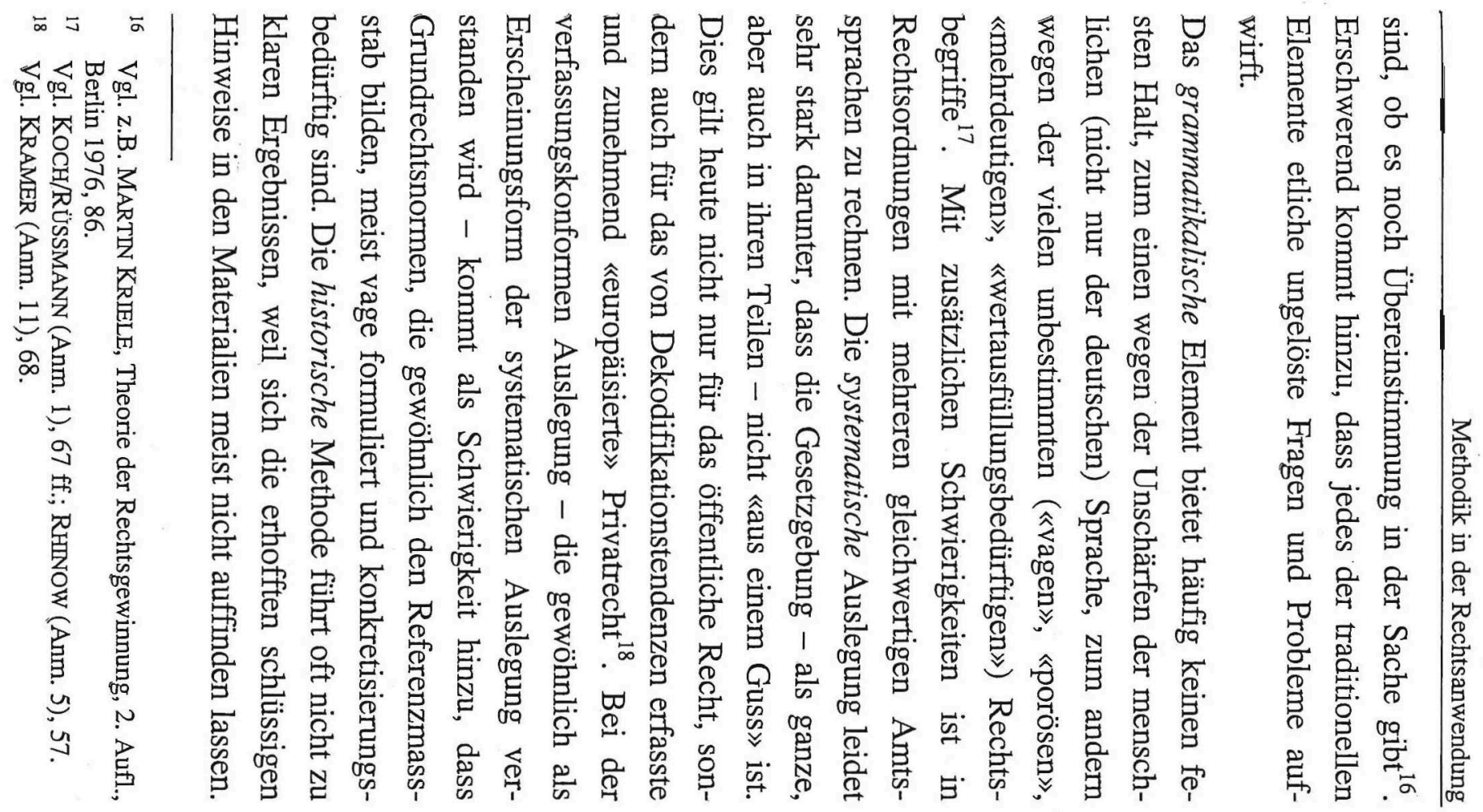


$\stackrel{w}{\mp}$ r

5

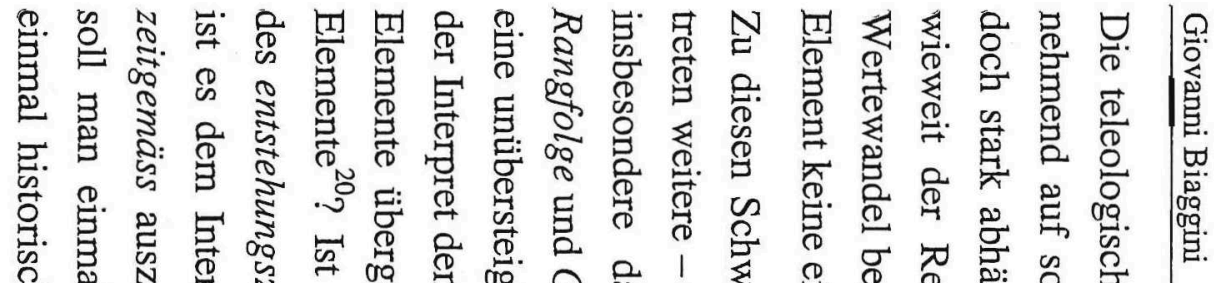

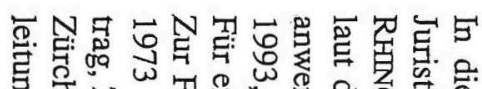

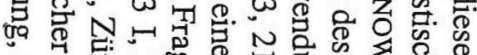

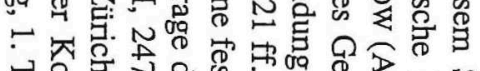

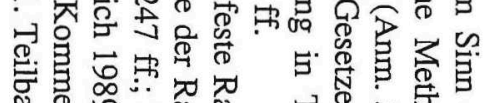

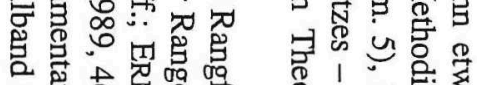

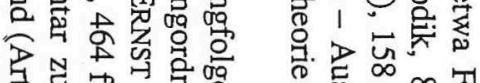

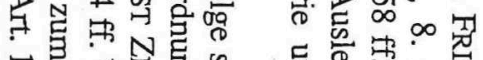

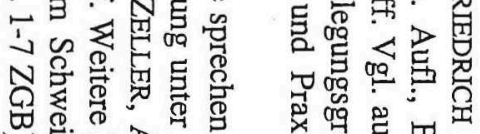

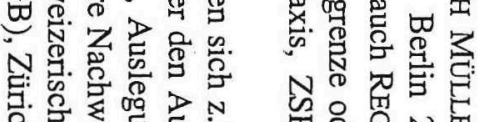

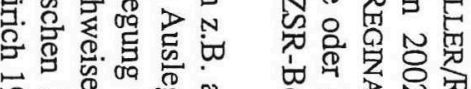

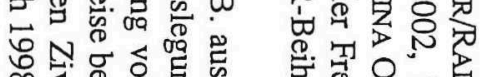

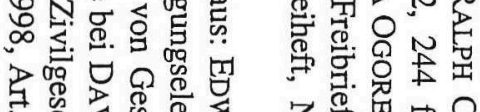

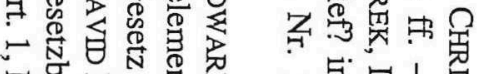

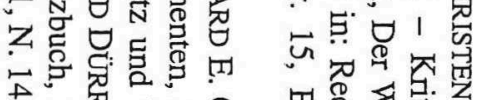

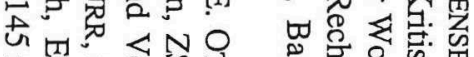

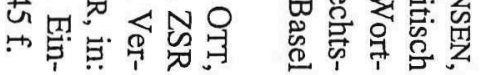

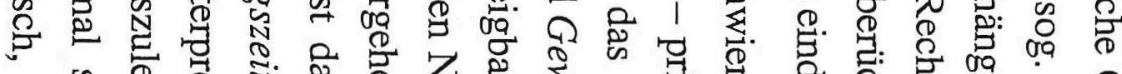

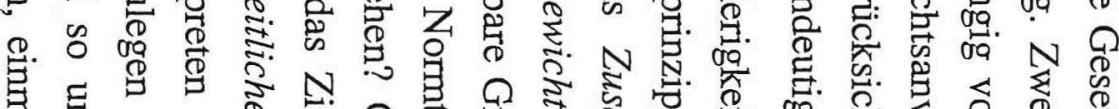

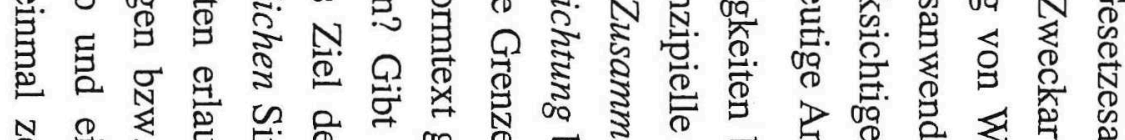

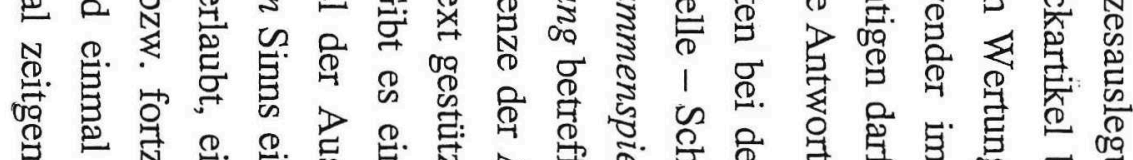

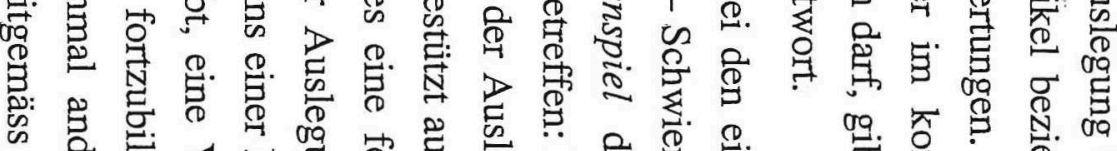

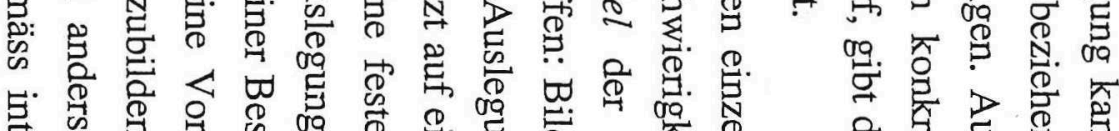

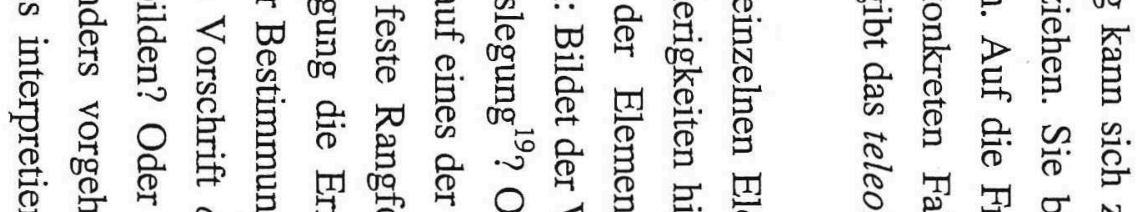

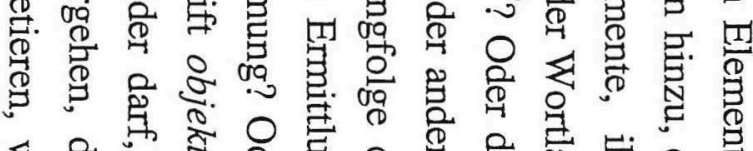

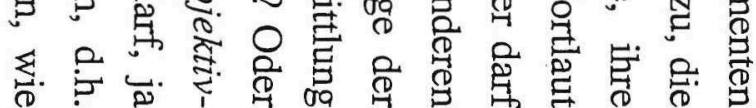

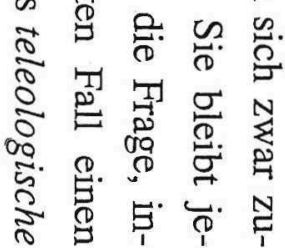

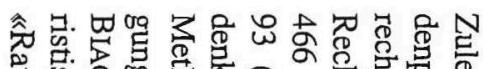

$\simeq$

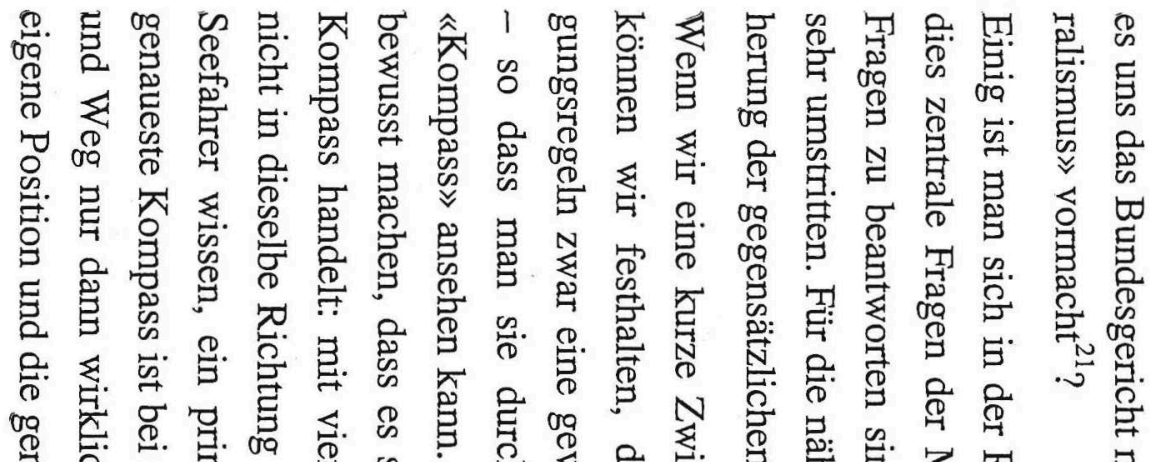

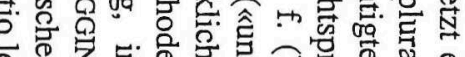

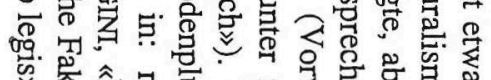

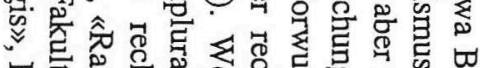

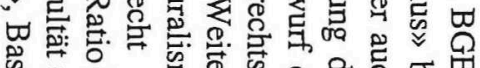

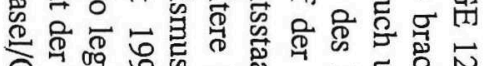
Q

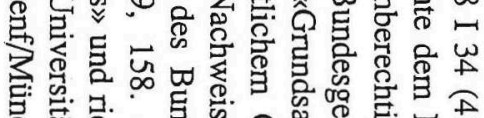

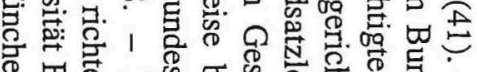

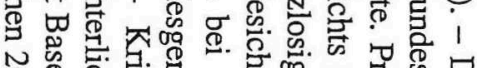

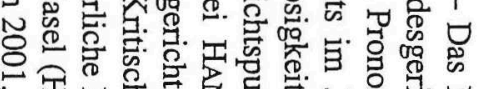

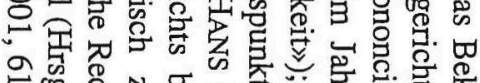

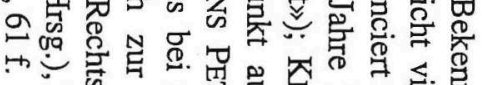

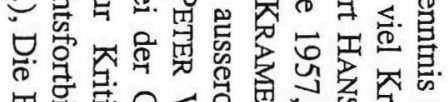

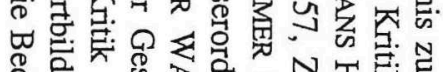

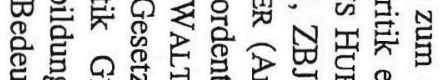

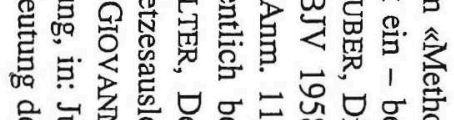

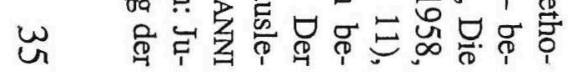

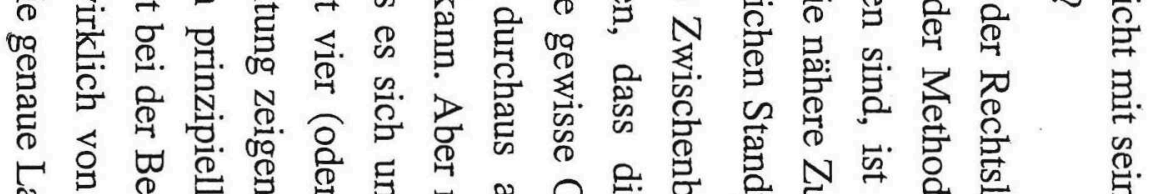

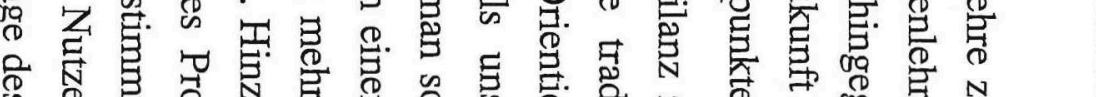

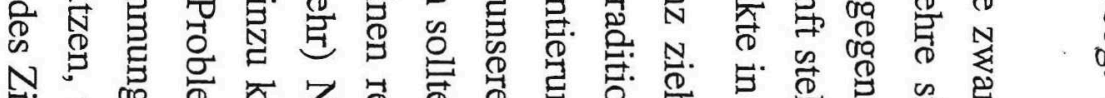

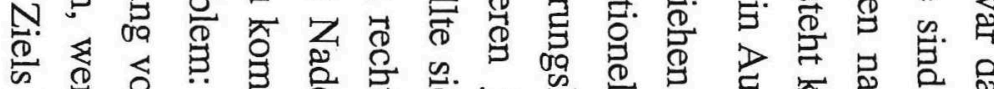

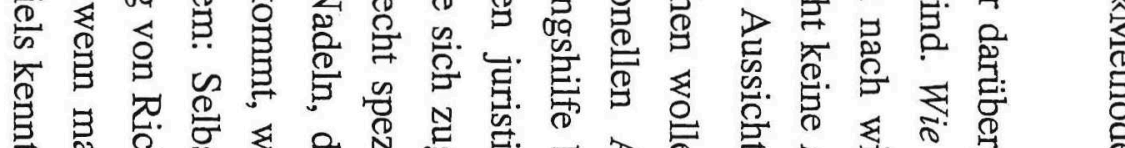

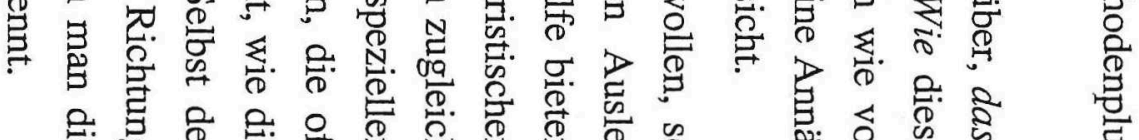

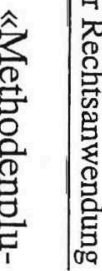



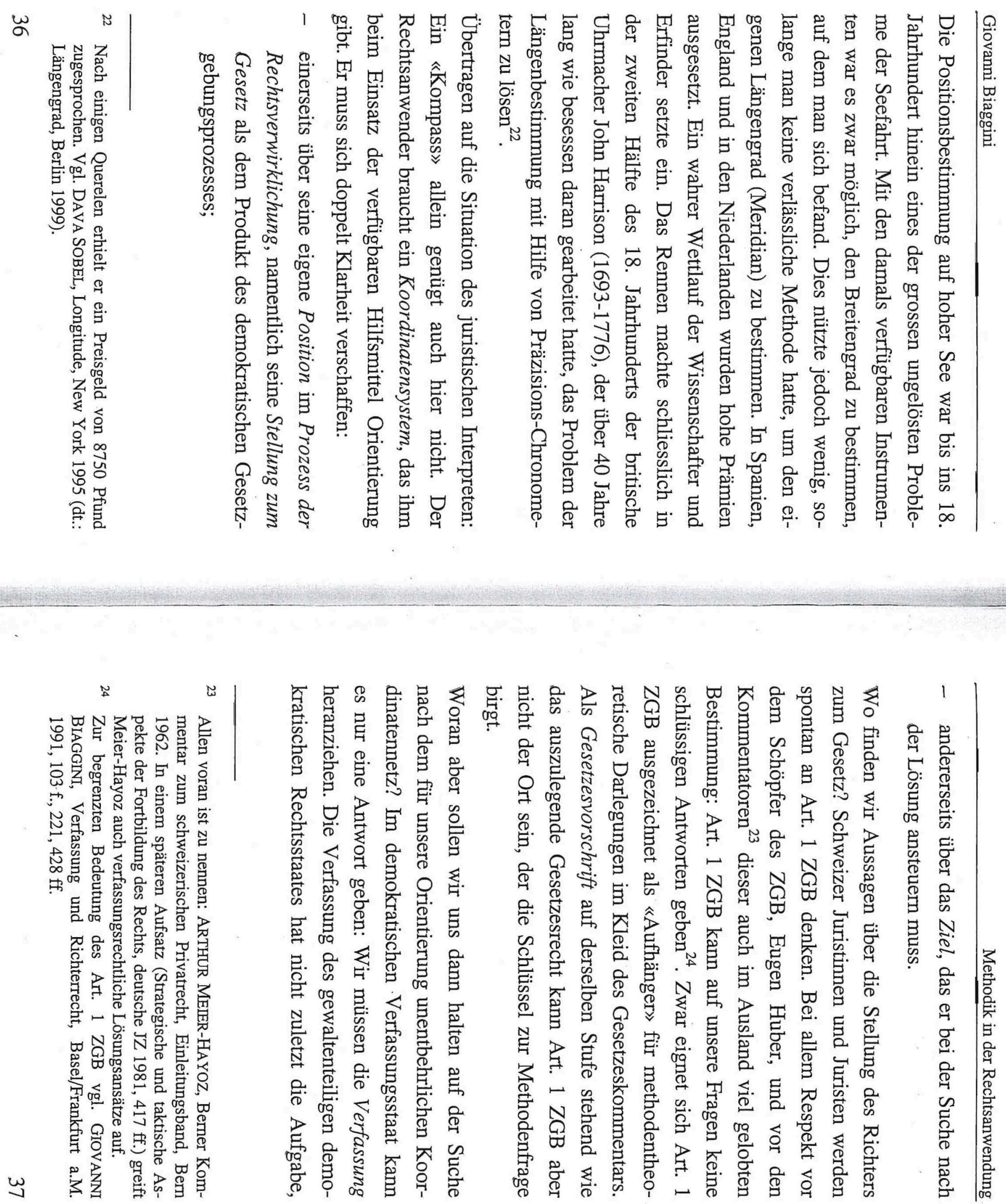

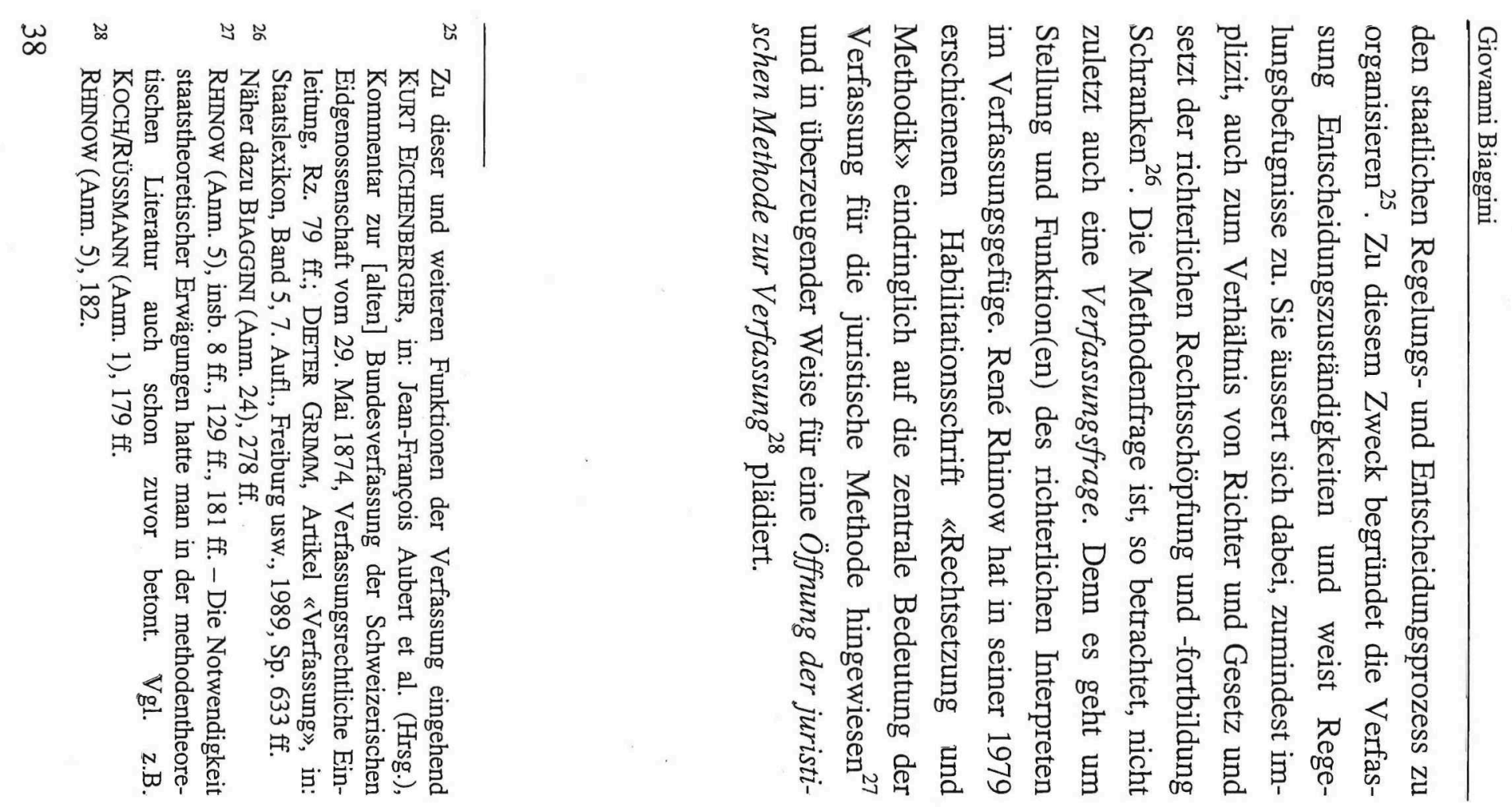

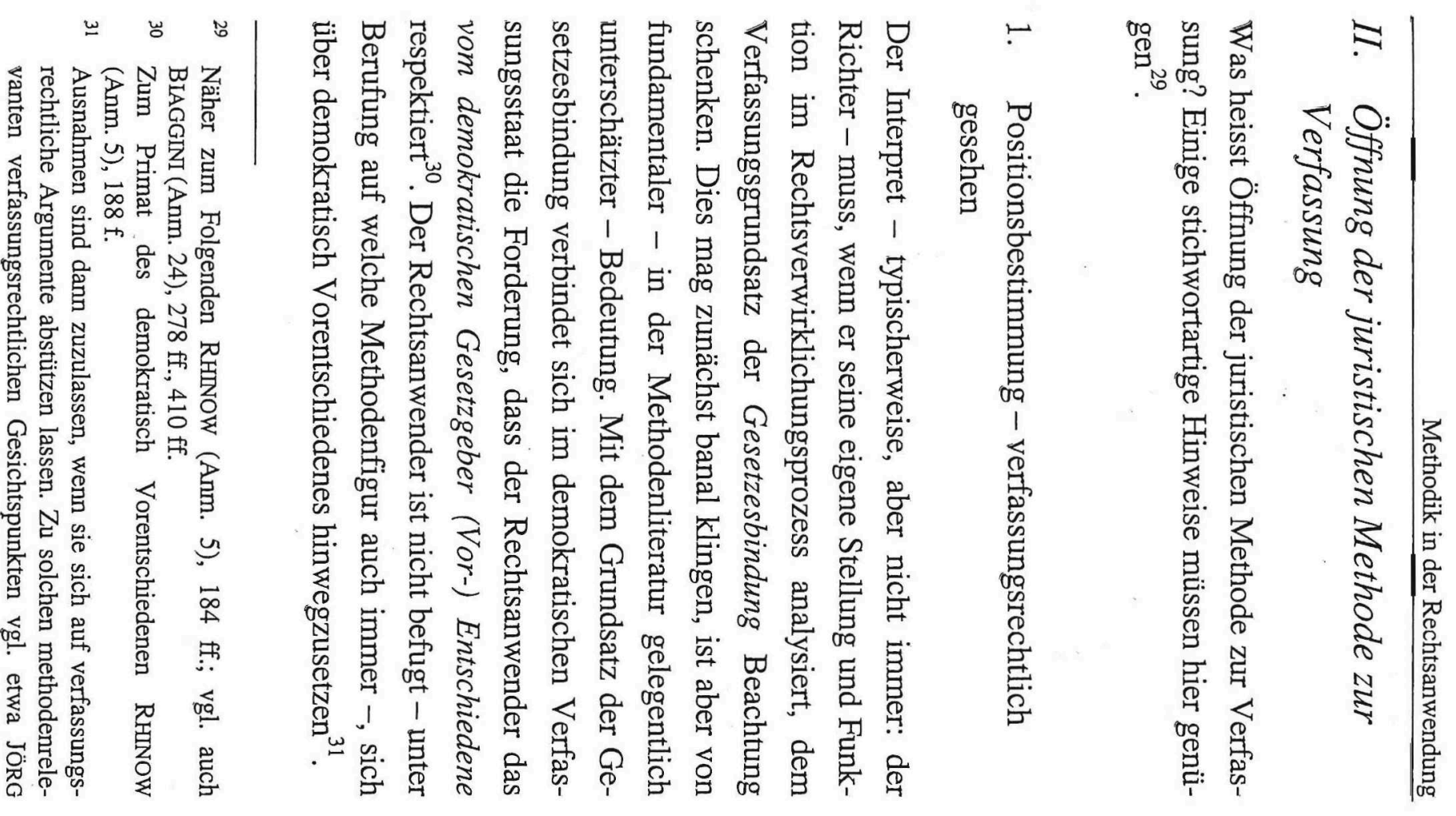



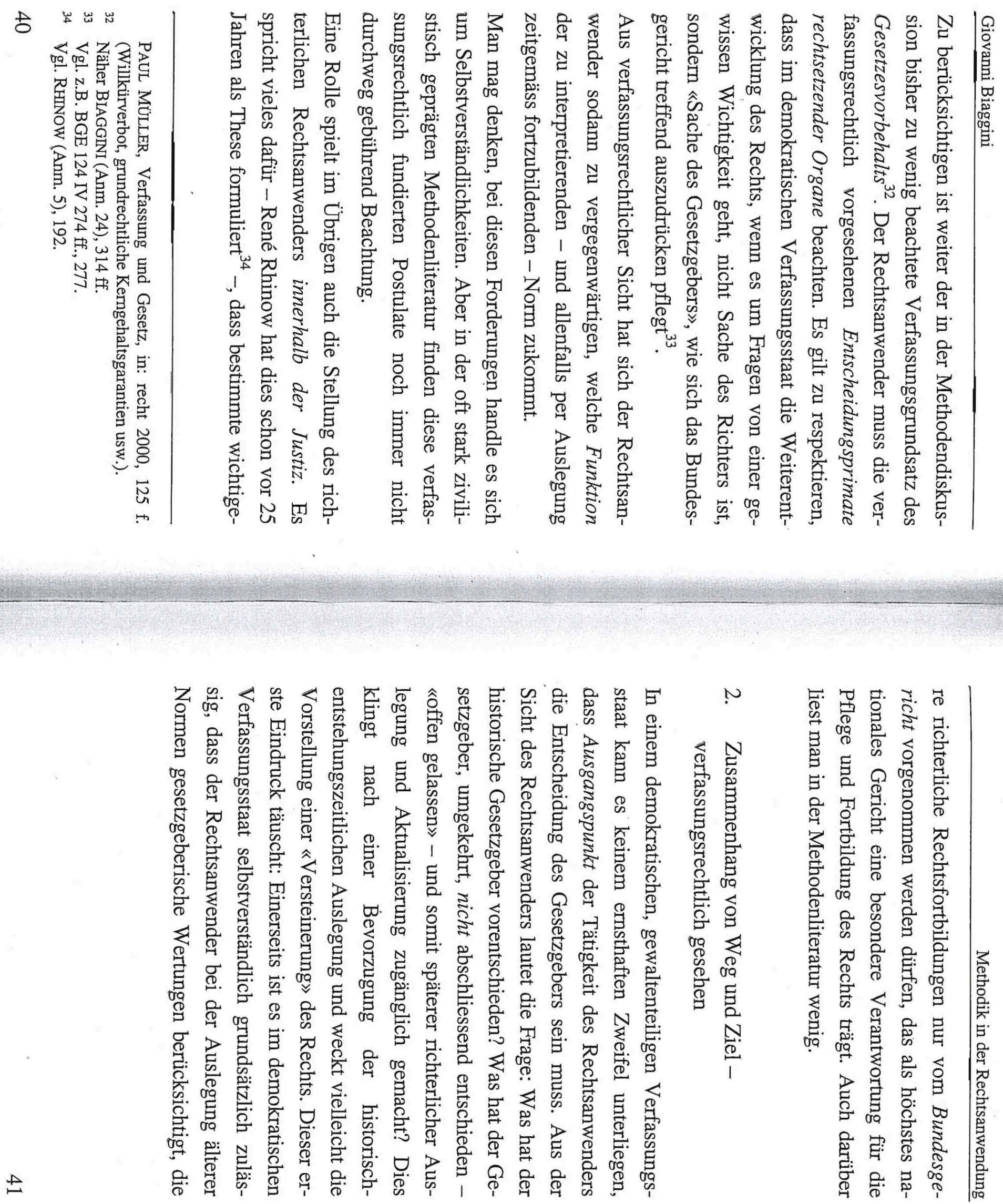
A

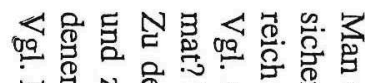

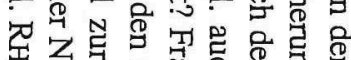

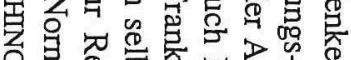

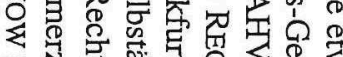

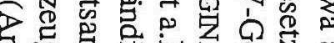

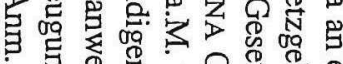

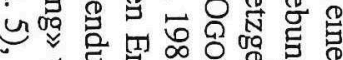

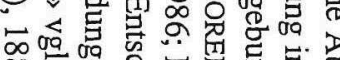

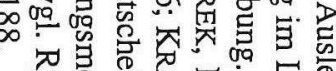

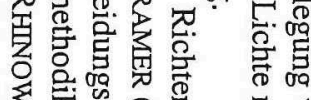

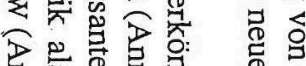

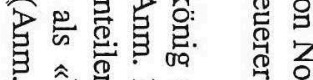

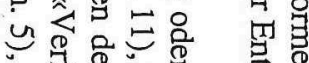

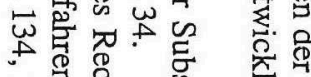

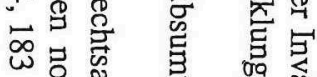
象自

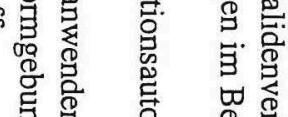

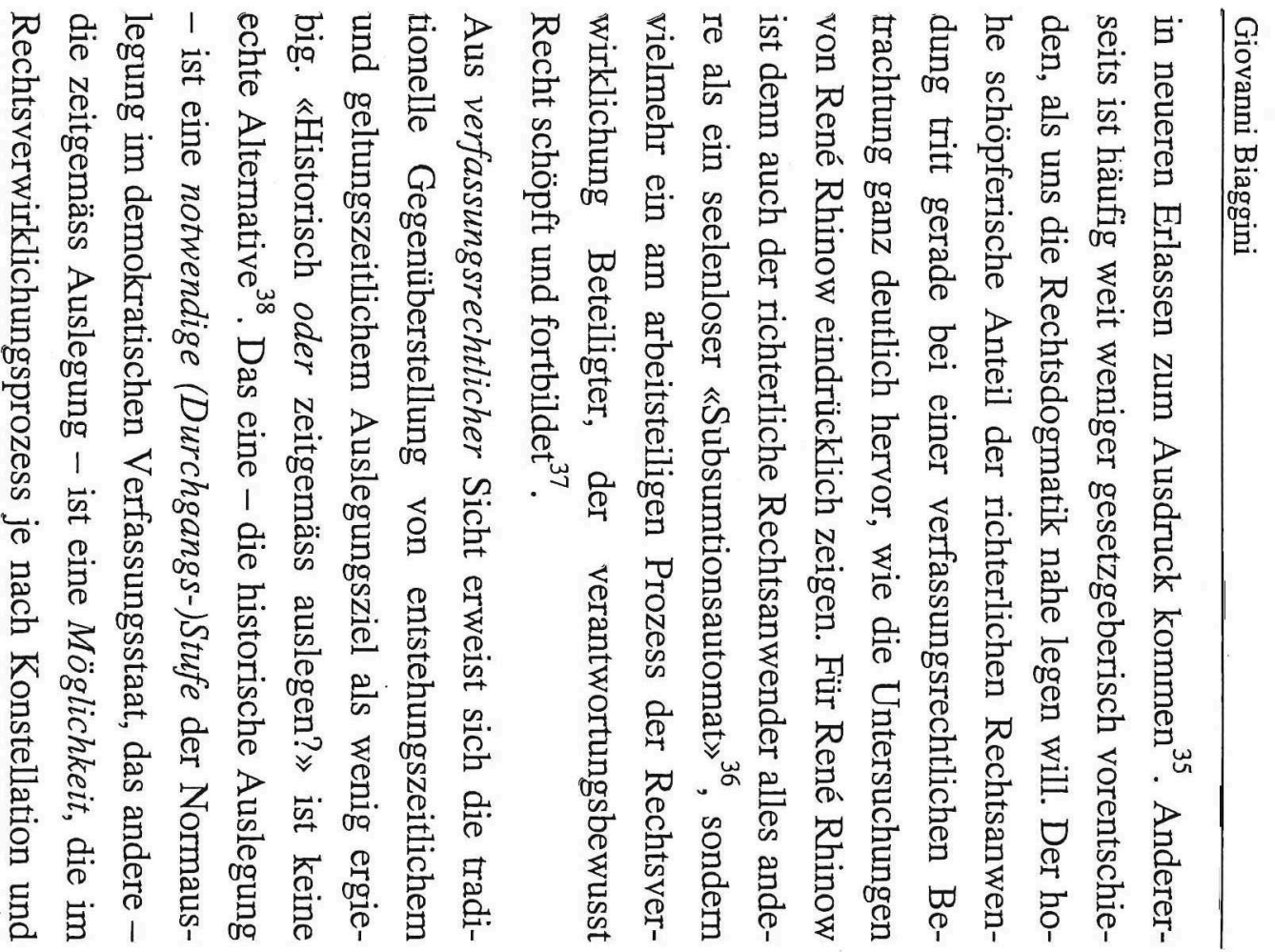

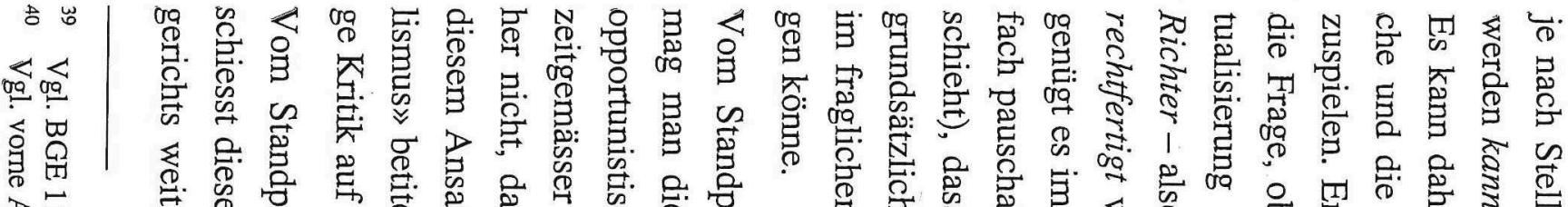

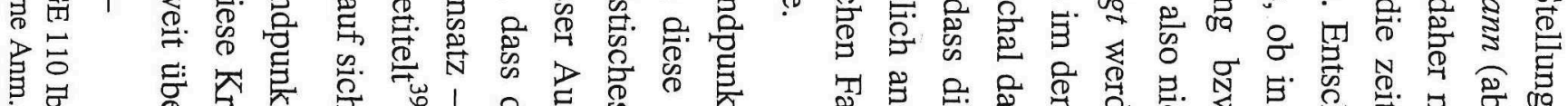

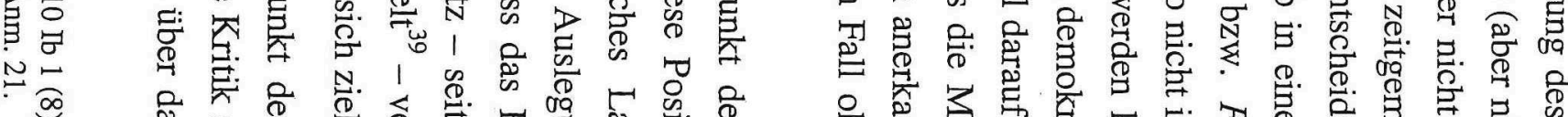

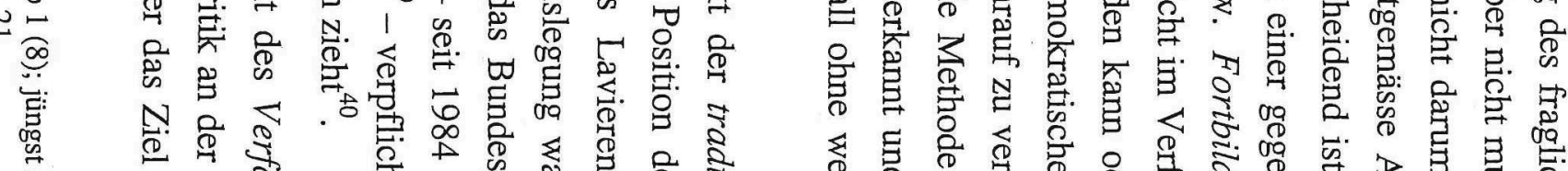

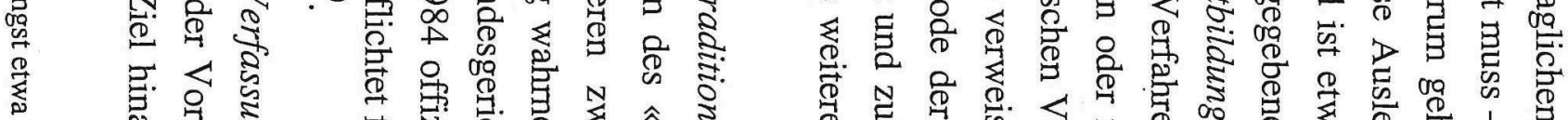

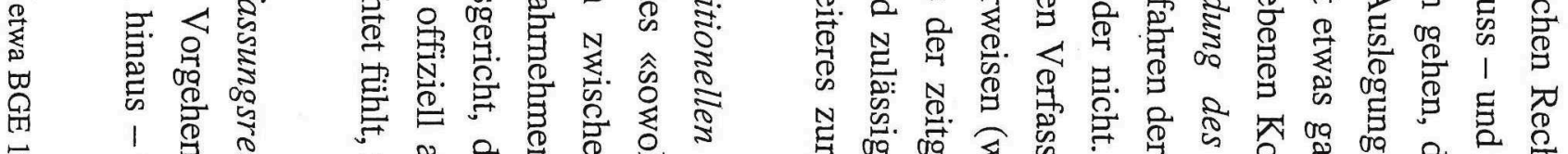

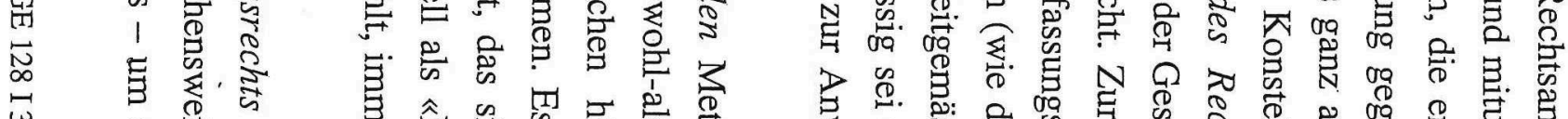

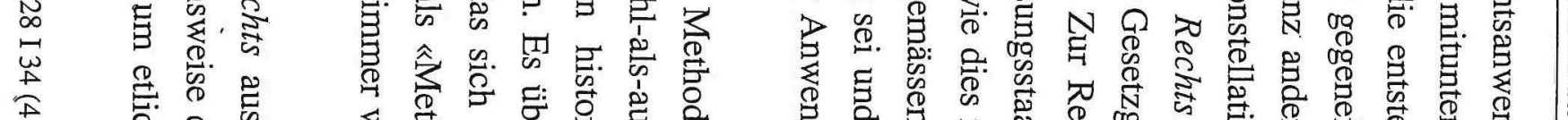

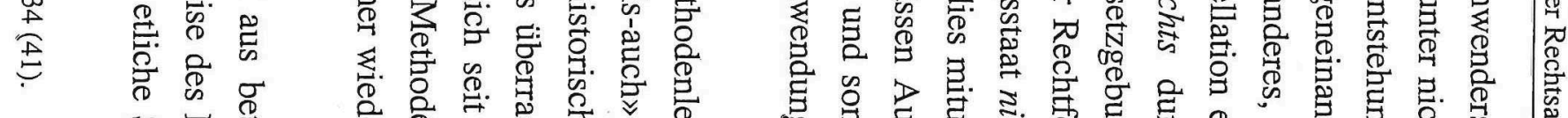

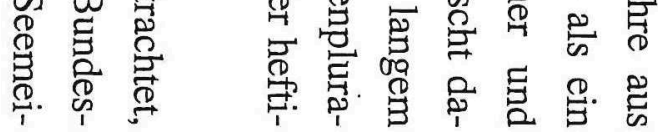
o

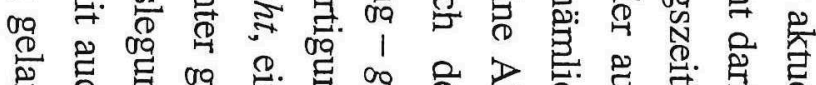



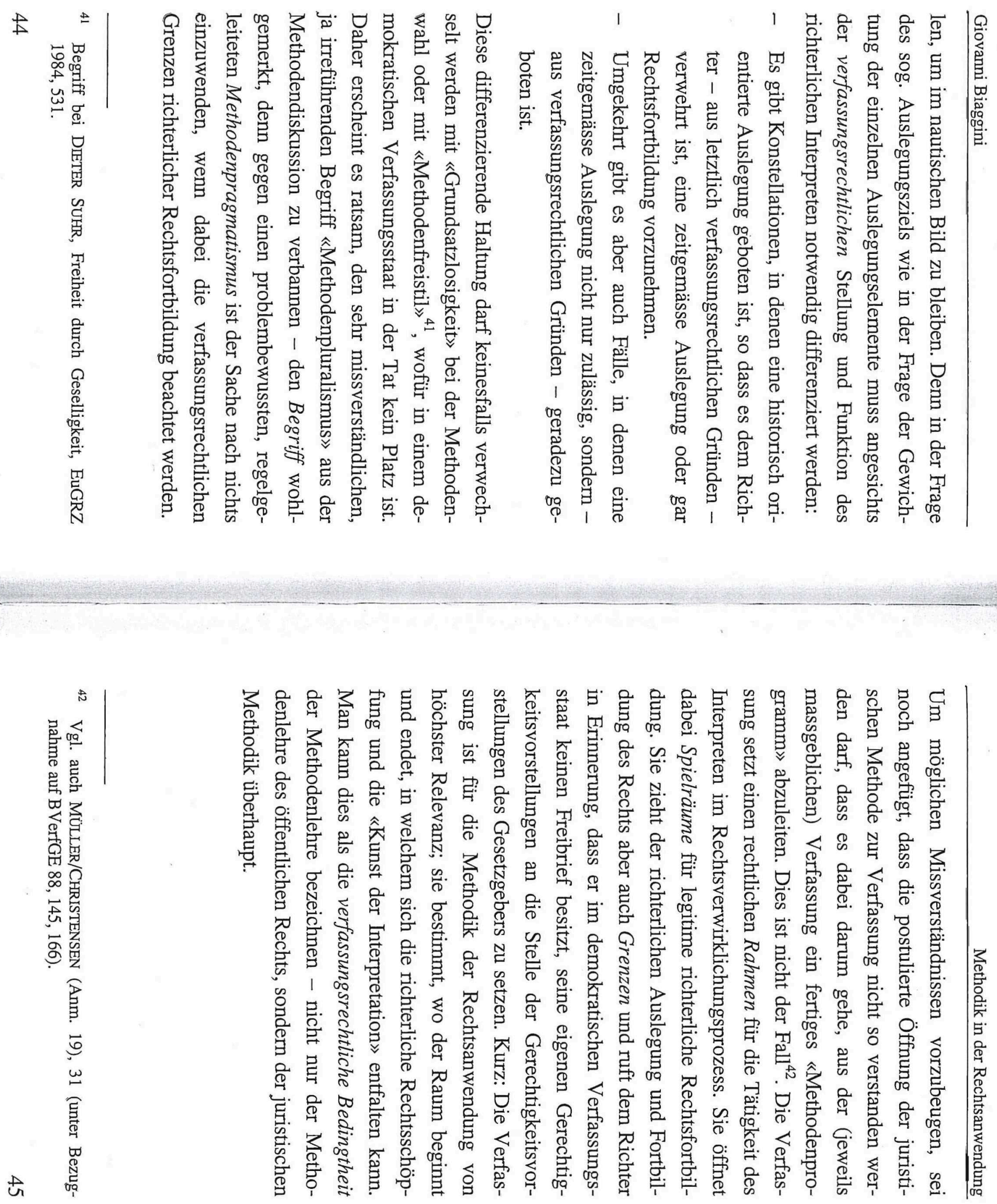

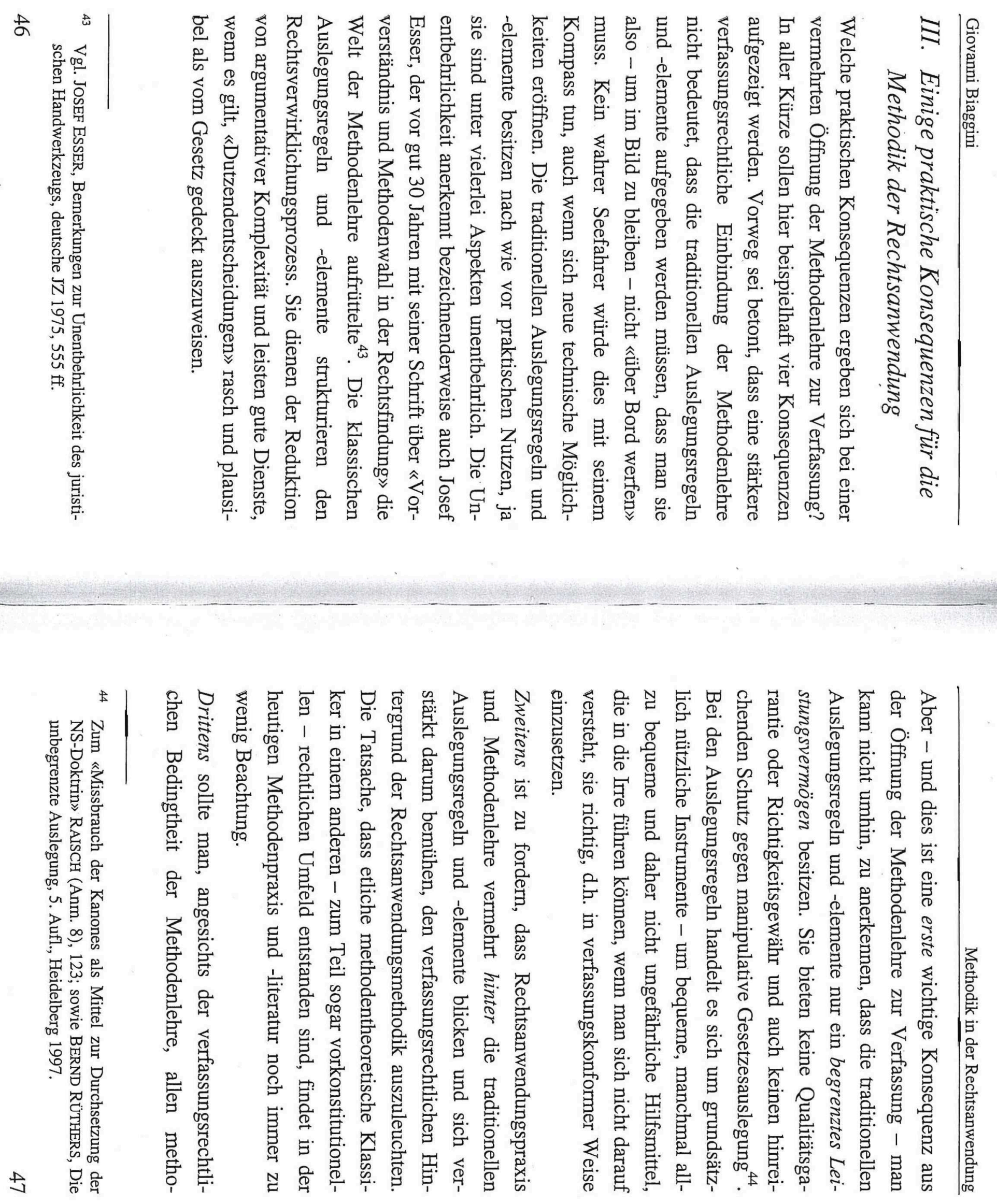
$\stackrel{\infty}{\infty}$

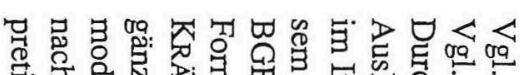
‥

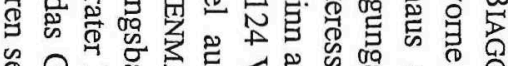

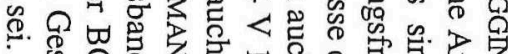

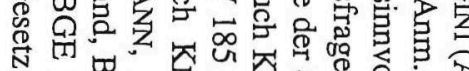

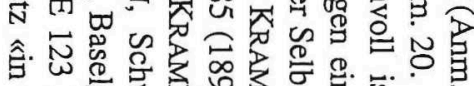

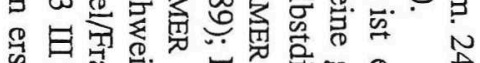

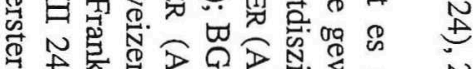

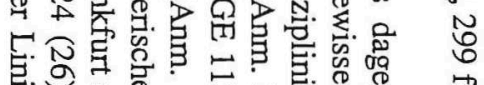

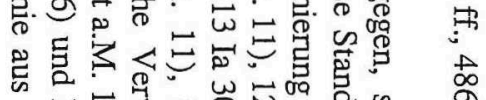

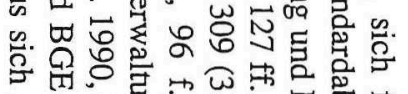

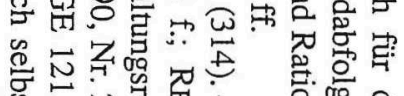

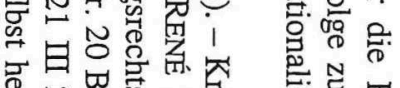

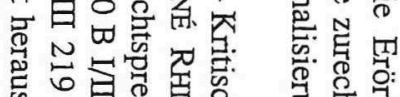

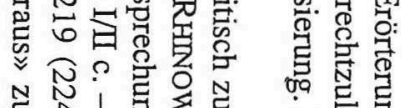

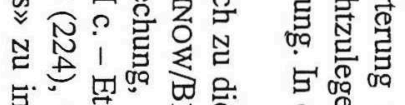

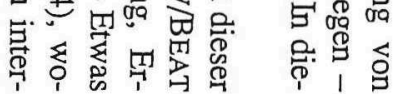

西

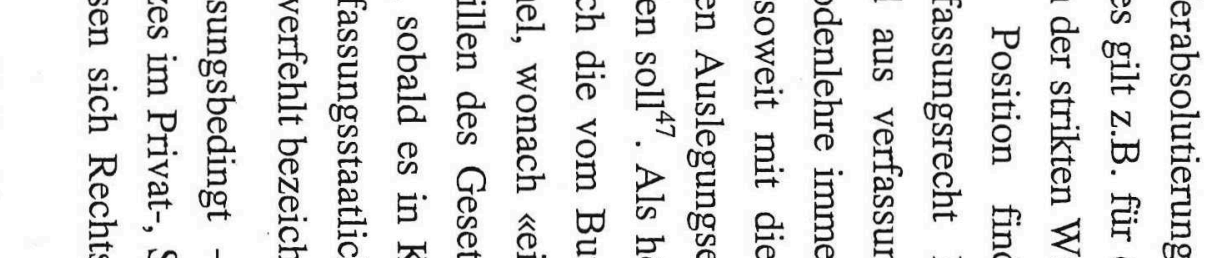

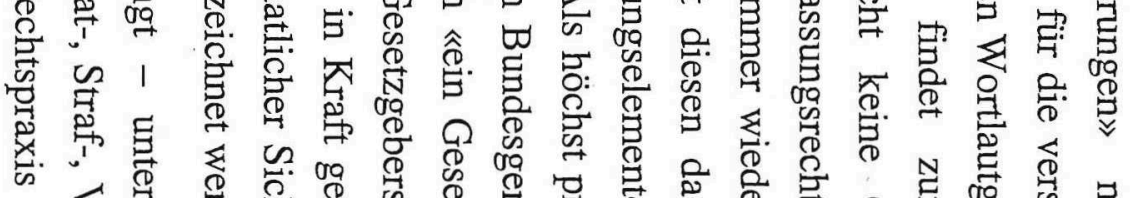

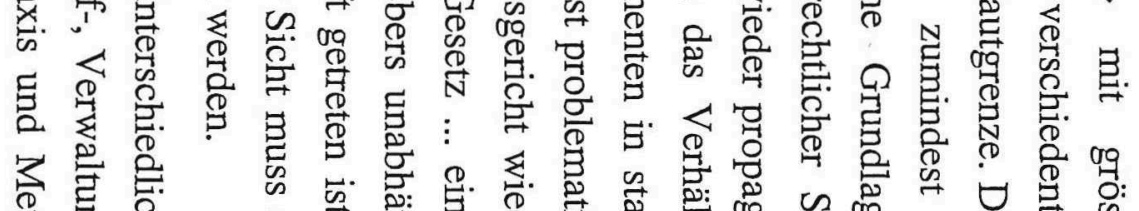

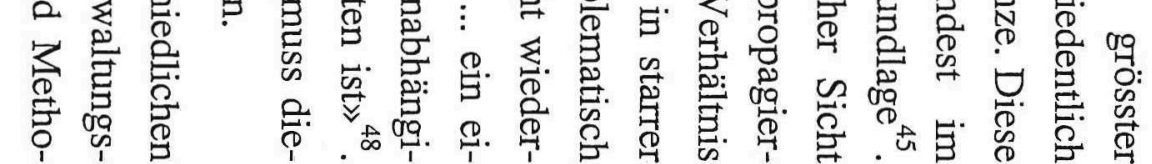

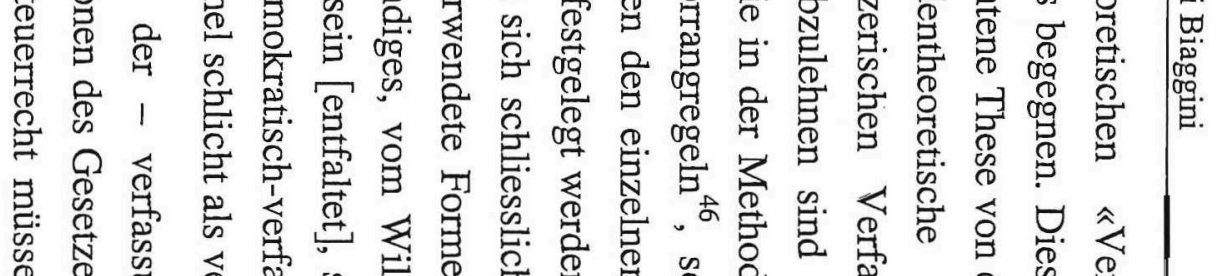

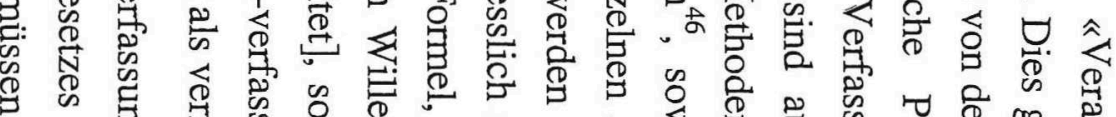

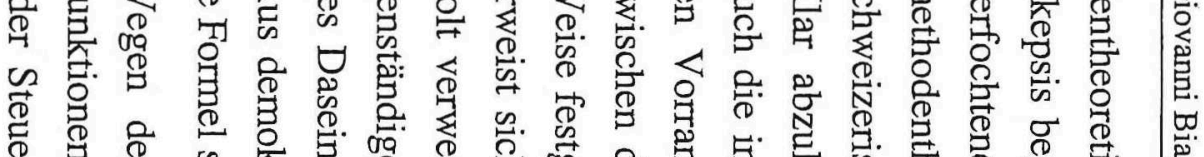

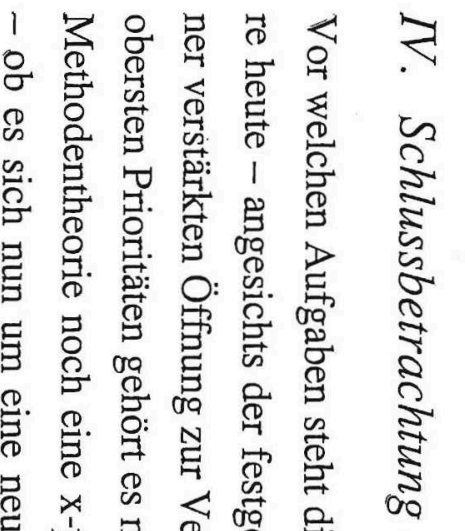

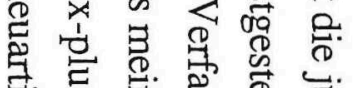

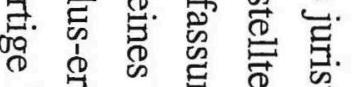

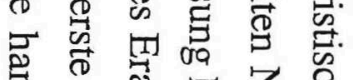

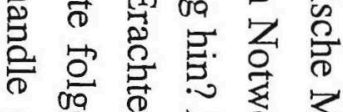

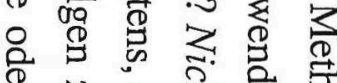

일

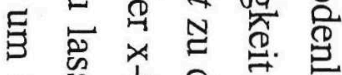

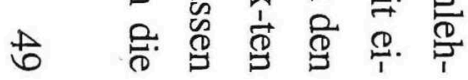

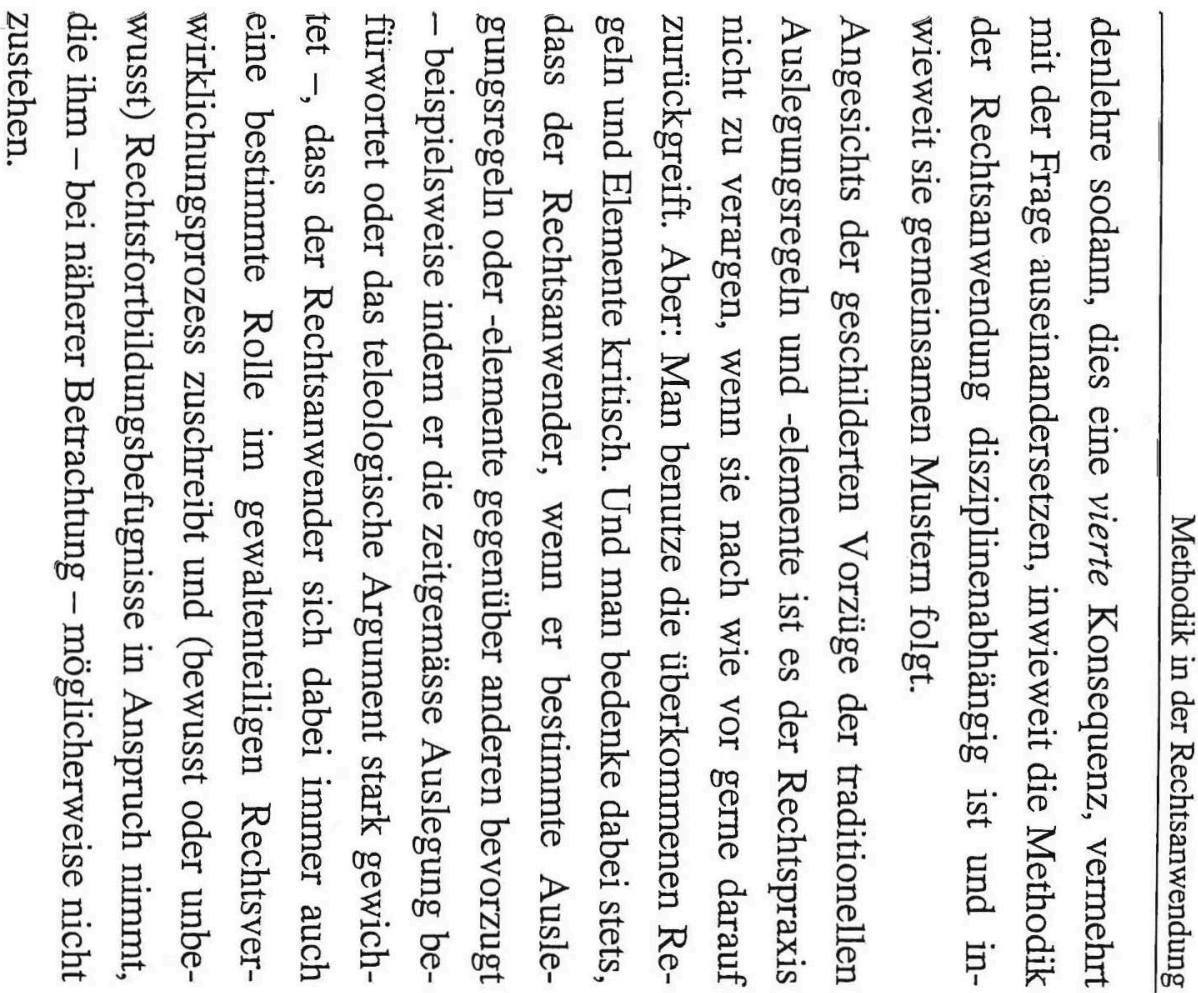


पy

능 古

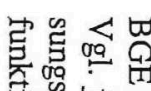

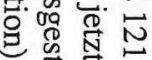

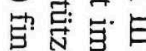

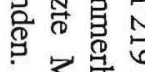

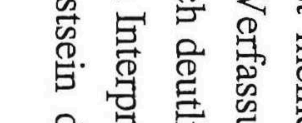

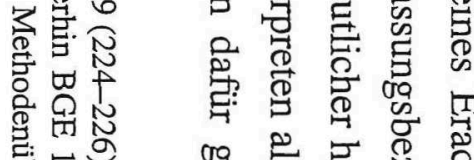

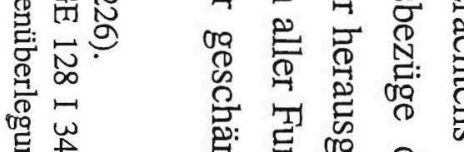

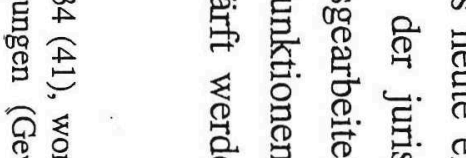

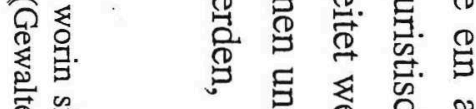

$\stackrel{\overrightarrow{9}}{\mathrm{C}}$

急量.

㭝芯

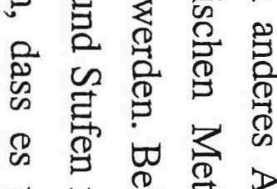

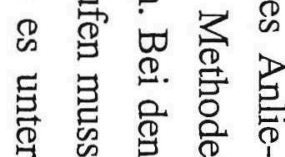

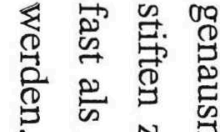

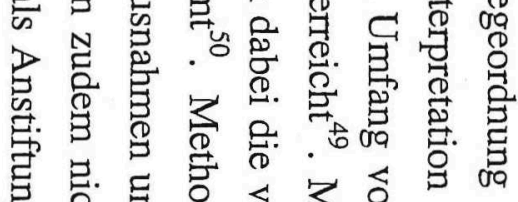

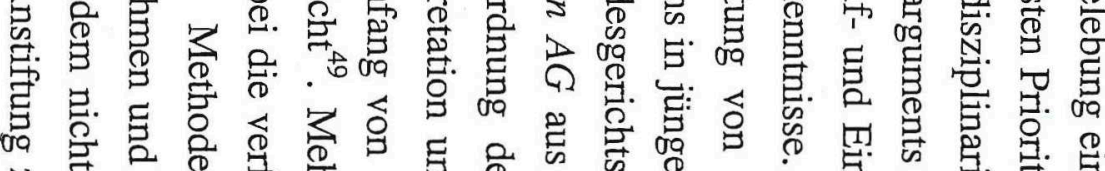

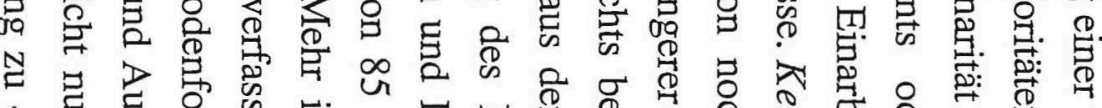

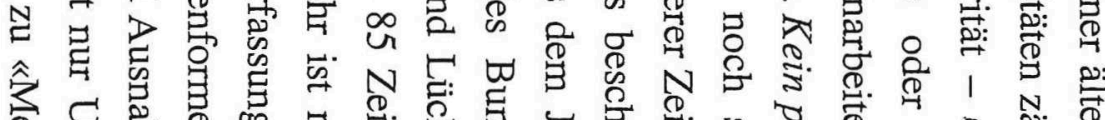

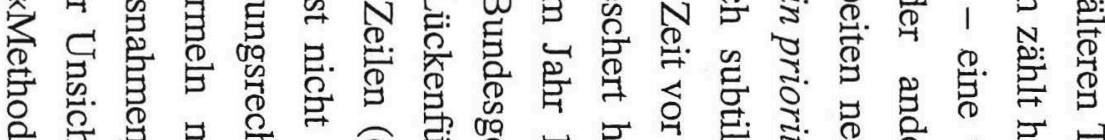

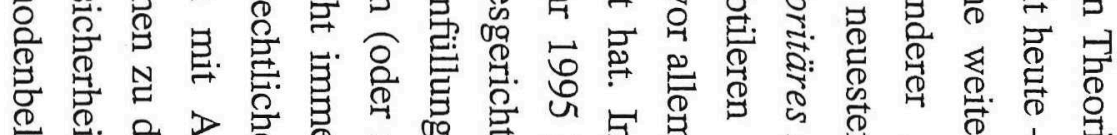

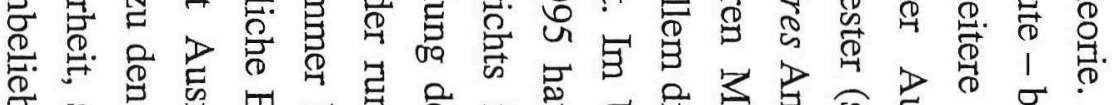

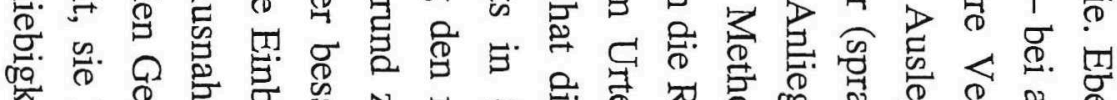
突. 范 总勇总

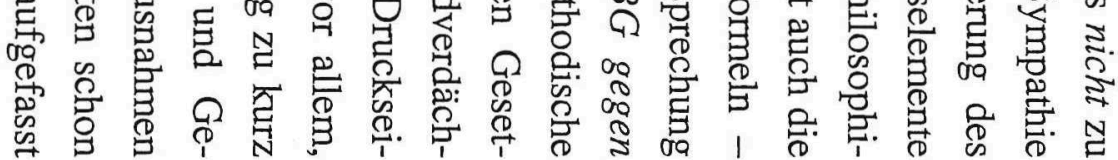

